\title{
Increased Thymic Hormone Responsive Suppressor T Lymphocyte Function in Chronic Active Hepatitis
}

\author{
MILTON G. MUTCHNICK, MD, JOHN A. SCHAFFNER, MD, JORGE A. PRIETO, MD, \\ FREDERICK E. WELLER, MA, and ALLAN L. GOLDSTEIN, PhD
}

\begin{abstract}
Mitogen-induced suppressor $T$ lymphocyte function was evaluated in patients with chronic active hepatitis $(C A H)$. The in vitro effect of the biological response modifier, thymosin fraction 5, on the suppressive activity of peripheral blood mononuclear cells $(P B M)$ was also assessed. Suppressor cell activity was significantly decreased in patients with $C A H$ when compared to controls $(\mathrm{P}<0.001)$. In the absence of the inducing mitogen, thymosin-treated PBM from both patients and controls promoted enhancement of tritiated thymidine uptake by cocultured allogeneic lymphocytes. When thymosin-treated mononuclear cells were mitogen-activated; patients, but not the controls, showed a marked increase in suppressor activity $(\mathrm{P}<0.001)$. These results indicate that the polypeptides contained in thymosin fraction 5 can promote a helper effect in patients and controls. Furthermore, PBM from patients with CAH contain a subset of lymphocytes that can express a suppressive function following thymosin treatment. We conclude that thymosin fraction 5 can promote an in vitro restoration of suppressor $T$ cell function in patients with $\mathrm{CAH}$.
\end{abstract}

Chronic active hepatitis (CAH) represents the histological expression of diverse etiology associated with progressive destruction of hepatocytes. An immune-mediated disorder may be responsible for the perpetuation of hepatic injury observed in some patients with $\mathrm{CAH}(1-7)$. Abnormalities in immunoregulatory $T$ lymphocytes have been described in a variety of immune-associated disorders. These regulatory lymphocytes, termed suppressor and helper $\mathrm{T}$ cells, appear to modulate and regulate both cell-

\footnotetext{
Manuscript received February 22, 1982; revised manuscript received August 23, 1982; accepted September 6, 1982

From the Department of Medicine, University of Michigan Medical Center and the Ann Arbor VA Medical Center, Ann Arbor, Michigan; the Department of Biochemistry, The George Washington University School of Medicine and Health Sciences, Washington, DC.

This study was supported by the Veterans Administration.

Address for reprint requests: Dr. Milton G. Mutchnick, Department of Medicine, V.A. Medical Center, 2215 Fuller Road, Ann Arbor, Michigan 48105.
}

mediated and humoral immune responses (8-10). Defects in nonspecific suppressor cell function have been reported in CAH (11-14), which suggests that the normal state of tolerance to hepatocyte autoantigens may be compromised, resulting in increased autoreactive hepatocytotoxic effector cell activity $(14,15)$.

In previous work we have shown that thymosin fraction 5, an extract of calf thymus glands, decreases the in vitro cytotoxic activity of peripheral blood mononuclear cells (PBM) obtained from patients with $\mathrm{CAH}$ (16). Other investigators have utilized biologically active thymus-derived factors to treat patients with chronic virus-B hepatitis and observed in vivo improvements in $\mathrm{T}$ cell counts and in immune reactivity (17).

The thymus gland is critical for the development, growth, and function of lymphoid tissue and for the maintenance of immune balance (18). The mechanism by which the thymus exerts its control over $\mathrm{T}$ 
cell development is not clear, but a critical part of this control involves the elaboration of hormones which regulate the differentiation of precursor $T$ cells and influence the function of already differentiated peripheral T cells (19-22). Thymosin fraction 5 is composed of at least 16 polypeptides with differing biologic activities that can act individually, sequentially, or in concert to influence the development of T cell subpopulations (18). Thymosin has also been shown to exert specific effects on regulatory $\mathrm{T}$ cell function $(18,23-26)$.

Since thymosin fraction 5 contains polypeptides which can, at the same time, influence helper or suppressor activity, the present studies were undertaken to assess thymosin effects on the helper and suppressor activity of PBM obtained from patients with $\mathrm{CAH}$.

\section{MATERIALS AND METHODS}

Patients. Eighteen patients had CAH by clinical, biochemical, and histological criteria (27). The clinical and biochemical characteristics of these patients are summarized in Table 1 . There were 12 men and six women with an age range of $17-60$ years $(35.0 \pm 3.0$, means \pm SEM). All patients had symptoms and/or biochemical abnormalities in tests of liver function for at least six months prior to biopsy and inclusion in the study. Histologic findings included the presence of piecemeal necrosis and bridging necrosis in all patients. Four individuals had concomitant early cirrhosis. None of the 12 patients lacking hepatitis $B$ virus markers in their serum had clinical or morphological evidence to suggest alcohol abuse or exposure to known hepatotoxic agents. At the time of evaluation four patients were taking prednisone and 14 patients were untreated. Five untreated patients were subsequently placed on prednisone and evaluated once again one to four months after. Eighteen age- ( $35.4 \pm \mathbf{3 . 0}$ years) and sexmatched healthy volunteers not known to have current or previous liver disease were also studied. Patients and controls were excluded if they had malignancy, previous known immunodeficiency, a history of recent viral upper respiratory illness (28), or were recipients of blood transfusions within two months of the evaluation.

Isolation of PBM. Mononuclear cells were isolated from the peripheral blood of patients and controls using FicollHypaque gradients as previously described (16). PBM were resuspended at $5 \times 10^{6}$ cells $/ \mathrm{ml}$ in RPMI-1640 medium (Gibco, Grand Island, New York) enriched with vitamins, $2 \mathrm{mM}$ glutamine, penicillin (100 units $/ \mathrm{ml})$, streptomycin $(100 \mu \mathrm{g} / \mathrm{ml})$, and $10 \%$ heat-inactivated fetal calf serum (complete medium). Purified bovine thymosin fraction 5 was prepared (29) and stored at $-20^{\circ} \mathrm{C}$. Concentrations ranging from 50 to $400 \mu \mathrm{g} / \mathrm{ml}$ were used.

Helper and Suppression Assays. To measure helper and suppressor activity promoted by thymosin in the presence or absence of concanavalin A (Con A; Pharmacia Fine Chemicals, Piscataway, New Jersey), a mixed- lymphocyte-culture proliferation assay was used $(23,30)$ with modifications as previously described (31). In the initial culture, 0 or $20 \mu \mathrm{g}$ of thymosin in a constant volume $(0.1 \mathrm{ml})$ of complete medium was added to $1 \mathrm{ml}$ of the PBM suspension and incubated at $37^{\circ} \mathrm{C}$ for $24 \mathrm{hr}$ in a humidified $5 \% \mathrm{CO}_{2}$ and air atmosphere. Parallel tubes containing $1 \mathrm{ml}$ of the PBM suspension plus $0.1 \mathrm{ml}$ of complete medium were prepared for immediate use. The final volume in each tube was $1.1 \mathrm{ml}$. Following the 0 - or $24 \mathrm{hr}$ period of incubation, the PBM were resuspended, and $0.55 \mathrm{ml}$ of each tube was incubated in the presence or absence of Con A ( $5 \mu \mathrm{g} / \mathrm{ml})$ for an additional $48 \mathrm{hr}$. These constituted the 2-day and 3-day initial cultures, respectively. After incubation the control and Con A-activated cells were treated with $50 \mu \mathrm{g} / \mathrm{ml}$ of mitomycin C (Sigma Chemical Co., St. Louis, Missouri) for $30 \mathrm{~min}$, and washed twice in $30 \mathrm{mM} \alpha$-methylmannoside and once again in complete medium. The PBM were resuspended at $1 \times 10^{6} \mathrm{cells} / \mathrm{ml}$ in complete medium.

Fresh PBM (responder cells) from a healthy donor were adjusted to $2 \times 10^{6} \mathrm{cells} / \mathrm{ml}$ in complete medium. For the coculture experiments, cells from the 2- and 3-day initial cultures were incubated with fresh allogeneic responder cells from the same donor for $90 \mathrm{hr}$. The studies were performed in quadruplicate in flat-bottom microtiter plates (Costar, Cambridge, Massachusetts) to which were added $0.05 \mathrm{ml}$ of responder PBM $\left(1 \times 10^{5}\right.$ cells $), 0.1 \mathrm{ml}$ of precultured PBM $\left(1 \times 10^{5}\right.$ cells $)$, and $0.05 \mathrm{ml}$ of complete medium containing Con A $(40 \mu \mathrm{g} / \mathrm{ml})$. In control wells $0.05 \mathrm{ml}$ of complete medium without Con A were added such that the total volume in each well was $0.2 \mathrm{ml}$. Tritiated thymidine, $2 \mu \mathrm{Ci}$ per well (New England Nuclear, Waltham, Massachusetts), was added $18 \mathrm{hr}$ prior to harvesting with an automatic multiple sample harvester (Otto Hiller Co., Madison, Wisconsin). The incorporation of $\left.{ }^{3} \mathrm{H}\right]$ thymidine into cells was measured in a Beckman liquid scintillation system.

Effect of Preincubation on Suppressor Activity. Recent studies have reported a decrease in Con A-induced șuppressor activity when PBM in initial culture are incubated for $24 \mathrm{hr}$ prior to activation with Con A (32-34). The influence of a 24-hr preincubation period on suppressor activity was determined to assess in vitro loss of suppressor cell activity (SCA) and to evaluate the suppressor cell response to preincubation in the presence of thymosin.

Calculations of Helper/Suppressor Activity. The suppression of allogeneic responder cells by PBM from the 2and 3-day initial cultures not containing thymosin was ealculated as: \% suppression $=1-(\Delta$ counts per minute $(\mathrm{cpm})$ suppressor cells $/ \Delta \mathrm{cpm}$ control cells) $\times 100$; where $\Delta \mathrm{cpm}=\mathrm{cpm}$ of Con A stimulated cocultures $-\mathrm{cpm}$ unstimulated cocultures; suppressor $=$ Con $A$ activated PBM from initial cultures; control $=$ PBM not activated with Con A in initial cultures. Thymosin effect in the 3day initial cultures was calculated as: $\%$ suppression $=1$ $-(\Delta \mathrm{cpm}$ thymosin pretreated suppressor cells $/ \Delta \mathrm{cpm}$ thymosin pretreated control cells) $\times 100$. The effect of thymosin alone on SCA in the absence of Con A induction in the initial cultures was determined as: $\%$ suppression $=1-(\Delta \mathrm{cpm}$ thymosin pretreated $\mathrm{PBM} / \Delta \mathrm{cpm}$ untreated $\mathrm{PBM}) \times 100$. A positive value indicated suppression of blast transformation in responder cells, and a 
MUTCHNICK ET AL

Table 1. Clinical Data of 18 Patients with CAH

\begin{tabular}{|c|c|c|c|c|c|c|c|c|}
\hline Patient & Age & Sex & $\underset{\text { histology }}{\text { Liver }}$ & Therapyt & $H B_{s} A g / H B_{s} A b / H B_{c} A b \neq$ & $A S M A / A N A \&$ & $\begin{array}{l}S G P T \| \\
\text { (IU/liter) }\end{array}$ & $\begin{array}{c}\gamma \text {-globulin } \\
(\mathrm{gm} / \mathrm{dl})\end{array}$ \\
\hline 1 & 17 & $\mathbf{M}$ & $\mathrm{CAH}$ & $\mathrm{O}$ & $-1-1-$ & $+1+$ & 680 & 2.4 \\
\hline 2 & 32 & $F$ & $\mathrm{CAH}$ & $\mathrm{O}$ & $-1-1-$ & $-1-$ & 365 & 3.0 \\
\hline 3 & 33 & $\mathbf{M}$ & $\mathrm{CAH}$ & $\mathrm{O}$ & $-1-1-$ & $-1-$ & 200 & 1.9 \\
\hline 4 & 24 & $\mathbf{M}$ & CAH & $\mathrm{O}$ & $-1-1-$ & $-1+$ & 880 & 2.1 \\
\hline 5 & 22 & $\mathbf{M}$ & CAH & $\mathrm{O}$ & $-1-1-$ & $-1-$ & 110 & 1.4 \\
\hline 6 & 19 & $\mathrm{~F}$ & CAH & $\mathrm{O}$ & $-1-1-$ & $+1-$ & 640 & 4.6 \\
\hline 7 & 26 & $\mathbf{M}$ & $\mathrm{CAH}-\mathrm{C}$ & $\mathrm{O}$ & $-1-1-$ & $-1-$ & 144 & 2.2 \\
\hline 8 & 27 & $F$ & $\mathrm{CAH}$ & $\mathrm{P}$ & $-1-1-$ & $+/ \mathrm{ND}$ & 81 & 2.9 \\
\hline 9 & 47 & $\mathbf{M}$ & $\mathrm{CAH}$ & $P$ & $-1-1-$ & $-1-$ & 65 & ND \\
\hline 10 & 47 & $\mathbf{F}$ & $\mathrm{CAH}-\mathrm{C}$ & 0 & $-1+1-$ & $-1-$ & 23 & 1.9 \\
\hline 11 & 54 & $\mathbf{M}$ & CAH & $\mathrm{O}$ & $+1-1+$ & $-1-$ & 156 & 2.3 \\
\hline 12 & 60 & $\mathbf{M}$ & $\mathrm{CAH}$ & $\mathrm{P}$ & $+1-+$ & $-1-$ & 405 & 3.8 \\
\hline 13 & 47 & $\mathrm{~F}$ & CAH & $\mathrm{P}$ & $-1-1-$ & $-1-$ & 550 & 2.1 \\
\hline 14 & 52 & $F$ & CAH-C & $\mathrm{O}$ & $-1+1+$ & $+1+$ & 302 & 2.7 \\
\hline 15 & 32 & $\mathbf{M}$ & CAH & 0 & $+1-1+$ & $+1-$ & 199 & 2.0 \\
\hline 16 & 36 & $\mathbf{M}$ & CAH-C & 0 & $-1-1-$ & $+1-$ & 112 & 3.0 \\
\hline 17 & 30 & $\mathbf{M}$ & CAH & $\mathrm{O}$ & $+1-1+$ & $-1-$ & 49 & 1.6 \\
\hline 18 & 25 & $\mathbf{M}$ & $\mathrm{CAH}$ & $\mathrm{O}$ & $+1-1+$ & $-1-$ & 109 & 2.3 \\
\hline
\end{tabular}

*CAH, chronic active hepatitis; CAH-C, chronic active hepatitis with cirrhosis.

$\dagger P$, prednisone; $O$, none.

$\Varangle \mathrm{HB}_{\mathrm{s}} \mathrm{Ag}$, hepatitis $\mathrm{B}$ surface antigen; $\mathrm{HB}_{\mathrm{s}} \mathrm{Ab}$, hepatitis $\mathrm{B}$ surface antibody; $\mathrm{HB}_{\mathrm{c}} \mathrm{Ab}$, hepatitis $\mathrm{B}$ core antibody; + , positive; - , negative.

§ASMA, anti-smooth muscle antibody; ANA, antinuclear antibody; ND, not determined.

|| Serum glutamic-pyruvic transaminase.

ISerum $\gamma$-globulin.

negative value reflected enhancement of responder cell transformation. Statistical evaluation of SCA in patients and controls was accomplished with Student's $t$ test. The significance of the modulation in SCA in the presence of thymosin was determined using Student's paired $t$ test.

\section{RESULTS}

Determination of Optimal Thymosin Concentration. We have previously shown that thymosin does not exert a mitogenic effect on PBM and, in healthy volunteers, maximum suppression of responder cells is observed when PBM in initial cultures are incubated with 10 and $20 \mu \mathrm{g} / \mathrm{ml}$ of thymosin (31). Similar results were seen when PBM from six patients with $\mathrm{CAH}$ were incubated in the absence of thymosin $(-0.53 \pm 2.4 ; \%$ suppression $\pm \mathrm{SEM})$ or with $5 \mu \mathrm{g} / \mathrm{ml}(-21.4 \pm 11.1), 10 \mu \mathrm{g} / \mathrm{ml}(9.8 \pm 2.7)$, $20 \mu \mathrm{g} / \mathrm{ml}(15.4 \pm 3.2)$, and $40 \mu \mathrm{g} / \mathrm{ml}(6.2 \pm 2.9)$ of thymosin. The effect of thymosin alone on the suppressive function of PBM was determined by omitting Con A from the initial cultures. A doseresponse was observed in patients and controls with enhancement rather than suppression of $\left[{ }^{3} \mathrm{H}\right]$ thymidine incorporation by Con A-stimulated responder cells. Maximal enhancement was observed at 10 and $20 \mu \mathrm{g} / \mathrm{ml}$ of thymosin. A thymosin concentra- tion of $20 \mu \mathrm{g} / \mathrm{ml}$ was therefore used for the remaining experiments.

Con A-Induced Suppression of Mixed-Lymphocyte-Culture Proliferation. The suppression of fresh allogeneic responder cells by PBM from the 2-day initial cultures is depicted in Figure 1 and Table 2. A significant decrease in SCA was observed in patients with $\mathrm{CAH}$, irrespective of seropositivity for the hepatitis B virus. No differences were noted between patients with $\mathrm{CAH}$ on prednisone treatment $(-0.5 \pm 4.6 \%$; mean \pm SEM $)$ and those not receiving medication $(-0.8 \pm 3.4 \% ; P=\mathrm{NS})$. SCA in the controls was substantially decreased in the 3day initial cultures not containing thymosin as compared to the 2-day initial cultures (Table 2). There was no corresponding change in the low SCA observed in the patient group.

Thymosin Effect on Suppressor and Helper Activity. Thymosin pretreatment of PBM in the 3-day initial cultures markedly increased SCA in the patient group as compared to parallel untreated cultures. The responses were the same when $\mathrm{CAH}$ patients were stratified by seropositivity for the hepatitis B virus or by the presence or absence of steroid therapy. Moreover, the suppression promoted by thymosin in the $\mathrm{CAH}$ group was virtually identical to that seen in the controls, in whom no 


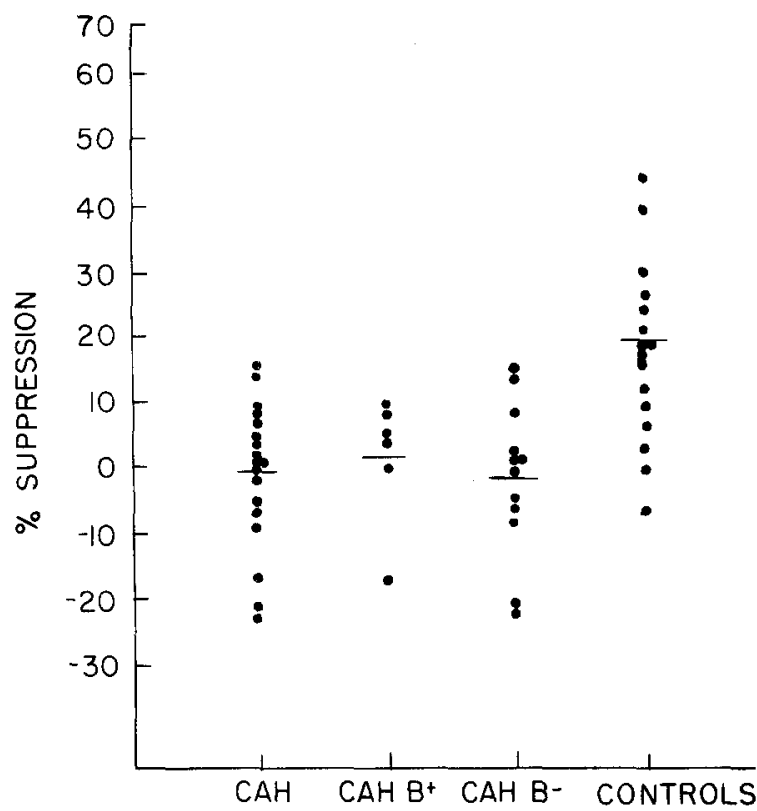

Fig 1. Con A-induced suppressor cell activity of peripheral blood mononuclear cells in 2-day initial cultures. $\mathrm{CAH}$, total group of patients with $\mathrm{CAH}$; $\mathrm{CAH} \mathrm{B}+$, hepatitis $\mathrm{B}$-positive subgroup; $\mathrm{CAH} \mathrm{B}-$, hepatitis B-negative subgroup.

significant change in SCA was observed after thymosin treatment (Table 2).

The influence of thymosin alone on SCA was determined by omitting Con A activation of suppressor cells in the 3-day initial cultures. Enhancement rather than suppression of Con A-stimulated blast transformation of allogeneic responder cells was observed in both the patient and control groups (Table 2).
Influence of Prednisone Treatment on SCA. Five patients were examined prior to and from one to four months after initiation of prednisone therapy at 10-20 mg daily. SCA in the 2-day initial cultures were not different before and after initiation of treatment $(2.5 \pm 4.0 \%$, before; $-0.1 \pm 8.7 \%$, after $)$. In a similar manner the response to thymosin did not differ before and after initiation of treatment.

Correlation Between SCA and Biochemical Tests of Liver Function. There were no individual correlations between the SCA observed in the 2-day initial cultures, the suppressor cell response to thymosin in the 3-day cultures, the level of enhancement promoted by thymosin alone, and biochemical tests of liver function including total bilirubin, SGOT, SGPT, alkaline phosphatase, and serum gamma globulin levels.

\section{DISCUSSION}

Our previous observation that thymosin fraction 5 decreased the in vitro cytotoxic activity of PBM from patients with CAH suggested that this biological response modifier influenced a subset of lymphocytes that directly mediated cytotoxic activity or that exerted immunoregulatory control over the actual effector cells (16). The initial report of a decrease in Con A-induced SCA in patients with $\mathrm{CAH}$ (11) prompted the present study to determine the effect of thymosin on suppressor T cell function. Subsequent investigations have also described alterations in suppressor activity in patients with $\mathrm{CAH}$ employing assays that monitor $\mathrm{T}$ cell suppression of pokeweed mitogen-induced immunoglobulin

Table 2. Effect of Incubation Time and Thymosin on Suppressor Cell Activity

\begin{tabular}{|c|c|c|c|c|c|}
\hline \multirow[b]{2}{*}{ Study group } & \multicolumn{3}{|c|}{ Initial cultures } & \multirow[b]{2}{*}{$\begin{array}{c}\text { Suppression (\%, } \\
\text { mean } \pm \text { SEM) }\end{array}$} & \multirow[b]{2}{*}{$\mathrm{P}$ value } \\
\hline & $\begin{array}{c}\text { Duration } \\
\text { (Days) }\end{array}$ & $\begin{array}{l}P B M \text { treated } \\
\text { with thymosin }\end{array}$ & $\begin{array}{c}\text { Con } A \\
\text { activation }\end{array}$ & & \\
\hline $\mathrm{CAH}(18)^{*}$ & 2 & 0 & + & $-0.9 \pm 2.7$ & $<0.001$ \\
\hline Controls (18) & 2 & 0 & + & $19.8 \pm 4.3$ & \\
\hline $\mathrm{CAH}(18)$ & 3 & 0 & + & $-1.3 \pm 4.0$ & $<0.05$ \\
\hline Controls (18) & 3 & 0 & + & $7.7 \pm 1.9 \dagger$ & \\
\hline $\mathrm{CAH}(18)$ & 3 & + & + & $12.9 \pm 3.1 \ddagger$ & NS \\
\hline Controls (18) & 3 & + & + & $11.2 \pm 1.9$ & \\
\hline $\mathrm{CAH}(18)$ & 3 & + & 0 & $-13.8 \pm 2.8$ & NS \\
\hline Controls (18) & 3 & + & 0 & $-8.6 \pm 3.3$ & \\
\hline
\end{tabular}

*Numver of subjects tested given in parenthesis

$\dagger P<0.02$ compared to 2-day initial cultures of controls, Student's $t$ test.

$\ddagger P<0.001$ compared to 3-day initial cultures in the absence of thymosin, Student's paired $t$ test. 
synthesis (12), mitogen (Con-A) -induced suppressor T cells (14), short-lived suppressor T cells (13), prostaglandin-producing suppressor (monocyte) cells (35), and spontaneous suppressor (monocyte) cells (14).

In preliminary work we noted that PBM from patients with $\mathrm{CAH}$ required a 24-hr incubation with thymosin in order to elicit an increase in SCA. This requirement for a $24-\mathrm{hr}$ preculture introduced the possibility that a loss in short-lived suppressor cells might occur in the 3-day initial cultures. These cells appear to constitute a distinct group of Con-A inducible suppressor cells $(33,34,36)$.

As shown in Table 2, there was a significant decrease in SCA in the controls between the 2-day and 3-day initial cultures with no appreciable change in SCA seen in the patient group. Thus, if there were few suppressor cells present in the PBM of patients with $\mathrm{CAH}$, a 24-hr preculture period would not have influenced the already low suppressor activity. Conversely the "normal" suppressor activity in the controls would decrease with preincubation. Thymosin did not maintain the functional capacity of suppressor cells from the controls, but it did increase SCA in patients with CAH.

It is possible that there are increased numbers of precursor suppressor cells $(37,38)$ in patients with $\mathrm{CAH}$, but not in healthy controls, that differentiate into suppressor cells in the presence of thymosin with subsequent induction by Con $A$ into activated cells. This hypothesis is supported by studies reporting a suppression of the proliferative responses of human PBM to a variety of mitogens by a thymosin-induced suppressor $T$ cell generated from a precursor population $(39,40)$. Furthermore, it is not likely that thymosin decreased a helper $\mathrm{T}$ cell effect in patients with $\mathrm{CAH}$, resulting in an altered helper-suppressor balance, as we have shown that PBM incubated in the presence of thymosin alone promoted enhancement of proliferation in the responder cells (Table 2). Moreover, while thymosin has been shown to mediate a predominantly helper effect in normal human peripheral blood $\mathrm{T}$ cells, Con $\mathrm{A}$ induction can unmask the equivalent suppressor activity in thymosin-pretreated PBM to that observed in PBM from the same individual not pretreated with thymosin (31). Alternatively, thymosin may have corrected intrinsic suppressor cell defects in patients with $\mathrm{CAH}$ or countered the in vivo influence of extrinsic factors such as immune complexes and antibodies to suppressor cells which might impair suppressor cell function $(41,42)$. Con- ceivably, thymosin may have modulated the function of a suppressor $T$ cell subset which in turn regulates an effector-suppressor $\mathrm{T}$ subset (43).

Although conclusive evidence is lacking, the target lymphocyte influenced by thymosin is most likely a $\mathrm{T}$ cell. This hypothesis is based on the following observations. First, thymosin-treated human null cells possessing $T$ but not $B$ cell antigens will form $T$ cell $E$ rosettes (ER) (44). Furthermore, $B$ cell and monocyte numbers or function are not directly altered by thymosin $(45,46)$. Second, in vitro studies have shown that thymosin can increase both $\mathrm{T}$ cell $\mathrm{ER}$ and Con A-induced suppressor activity in patients with systemic lupus erythematosus (SLE) $(23,45)$. Thymosin-induced increases in $\mathrm{T}$ cell $\mathrm{ER}$, both in vitro and in vivo, have also been reported in patients with $\mathrm{CAH}(17,47)$. Third, studies in animals indicate that thymosin fraction 5 can induce in vitro suppressor cells which then inhibit the induction of cytotoxic $T$ cells in a mixed lymphocyte-tumor cell culture. These suppressor cells have been characterized as Thy 1-positive, nonadherent, short-lived $T$ cells (48).

A variety of immunopathologic disorders are associated with perturbations in immunoregulatory balance. Thus autoimmunity may result from deviations in the function of helper or suppressor cells (49). Interpretation of the suppressor cell dysfunction in $\mathrm{CAH}$ as reported in previous studies as well as the present study is difficult. All published reports have underscored the lack of an association between suppressor cell function and biochemical changes, clinical status, or the presence of steroid therapy. This inability to relate suppressor cell function in $\mathrm{CAH}$ to other parameters of disease activity (7) may imply that the described regulatory cell changes represent the consequences of, rather than the causes for, perpetuation of the disease state (50). On the other hand, the lack of a correlation between SCA and disease indicators may suggest that the suppressor cell defect in $\mathrm{CAH}$ is genetically predetermined and is a predisposing factor to initiation or perpetuation of the disease. Support for this viewpoint has been shown in studies where family members of patients with SLE, in whom suppressor cell defects are regularly found, also have suppressor cell defects in the absence of clinical disease (51).

It is apparent that the relationship between defective suppressor cell activity and the pathogenesis of $\mathrm{CAH}$ requires further examination. The present study suggests that the PBM of patients with CAH 
contain a subset of $\mathrm{T}$ lymphocytes which, in the presence of thymic hormone, can express suppressor function following Con $\mathrm{A}$ induction. This raises the intriguing prospect that there may be an alteration in thymic regulation of $\mathrm{T}$ cell differentiation and function in patients with $\mathrm{CAH}$.

\section{REFERENCES}

1. Doniach D: Autoimmunity in liver diseases. Prog Clin Immunol 1:45-70, 1972

2. Wands JR, Isselbacher KJ: Lymphocyte cytotoxicity to autologous liver cells in chronic active hepatitis. Proc Natl Acad Sci USA 72:1301-1303, 1975

3. Hopf U, Meyer zum Buschenfelde KH, Arnold W: Detection of a liver-membrane antibody in $\mathrm{HB}_{\mathrm{s}} \mathrm{Ag}$-negative chronic active hepatitis. N Engl J Med 294:578-582, 1976

4. Jensen DM, McFarlane IG, Portmann BS, Eddleston ALWF, Williams R: Detection of antibodies directed against a liver-specific membrane lipoprotein in patients with acute and chronic active hepatitis. N Engl J Med 299:1-7, 1978

5. Eddleston ALWF, Weber JCP, Williams R: Immune Reactions in Liver Disease. London, Pitman Medical Publishing Co Ltd, 1979

6. Smith CI, Cooksley WGE, Powell LW: Cell-mediated immunity to liver antigen in toxic liver injury. 1. Occurrence and specificity. Clin Exp Immunol 39:607-617, 1980

7. Chisari FV, Bieber MS, Josepho CA, Xavier C, Anderson DS: Functional properties of lymphocyte subpopulations in hepatitis B virus infection. II. Cytotoxic effector cell killing of targets that naturally express hepatitis B surface antigen and liver-specific lipoprotein. J Immunol 126:45-49, 1981

8. Reinherz EL, Schlossman SF: Regulation of the immune response-inducer and suppressor T-lymphocyte subsets in human beings. N Engl J Med 303:370-373, 1980

9. Reinherz EL, Moretta L, Roper M, Breard JM, Mingarin MC, Cooper MD, Schlossman SF: Human T lymphocyte subpopulations defined by $\mathrm{Fc}$ receptor and monoclonal antibodies. A comparison. J Exp Med 151:969-974, 1980

10. Germain RN, Benacerraf B: Helper and suppressor $\mathrm{T}$ cell factors. Springer Semin Immunopathol 3:93-127, 1980

11. Hodgson HJF, Wands JR, Isselbacher $\mathrm{KJ}$ : Alteration in suppressor cell activity in chronic active hepatitis. Proc Natl Acad Sci USA 75:1549-1553, 1978

12. Kakumu S, Kazuaki Y, Kashio T: Immunoregulatory T-cell function in acute and chronic liver disease. Gastroenterology 79:613-619, 1980

13. Tremolada F, Fattovich G, Panebianco G, Ongaro G, Realdi G: Suppressor cell activity in viral and non-viral chronic active hepatitis. Clin Exp Immunol 40:89-95, 1980

14. Chisari FV, Castle KL, Xavier C, Anderson DS: Functional properties of lymphocyte subpopulations in hepatitis $B$ virus infection. 1. Suppressor cell control of $T$ lymphocyte responsiveness. J Immunol 126:38-44, 1981

15. Savary CA, Lotzova E: Suppression of natural killer cell cytoxicity by splenocytes from Corynebacterium parvurninjected, bone marrow-tolerant, and infant mice. J Immunol 120:239-43, 1978

16. Mutchnick MG, Missirian A, Johnson AG: Lymphocyte cytotoxicity in human liver disease using rat hepatocyte monolayer cultures. Clin Immunol Immunopathol 16:423437,1980

17. Dabrowski MP, Dabrowska-Bernstein BK, Brzosko WJ, Babiuch L, Kassur B: Immunotherapy of patients with chronic virus B hepatitis. 1. Maturation of human T-lymphocytes under influence of calf thymic hormone. Clin Immunol Immunopathol 16:297-307, 1980

18. Low TLK, Goldstein AL: Thymosin and other thymic hormones and their synthetic analogues. Springer Series Immunopathol 2:169-186, 1979

19. Goldstein AL, White A: Thymosin and other thymic hormones: Their nature and roles in the thymic dependency of immunological phenomena. In Contemporary Topics in Immunology. AJS Davis, RL Carter (eds). New York, Plenum Publishing Co, 1973, pp 339-350.

20. Schulof RS, Goldstein AL: Thymosin and the endocrine thymus. Adv Intern Med 22:121-143, 1977

21. White A, Goldstein AL: The endocrine role of the thymus, and its hormone thymosin in the regulation of the growth and maturation of host immunological competence. Adv Metab Dis 8:361-376, 1975

22. Naylor PH, Thurman GB, Goldstein AL: Cyclic nucleotide changes in immune lymphocytes following thymosin incubation in vitro. Immunopharmacology 1:89-101, 1979

23. Horowitz S, Borcherding W, Vishnu Moorthy A, Chesney $\mathrm{R}$, Schulte-Wissermann $\mathrm{H}$, Hong R: Induction of suppressor $T$ cells in systemic lupus erythematosus by thymosin and cultured thymic epithelium. Science 197:999-1001, 1977

24. Serrou B, Rosenfeld C, Caraux J, Thierry C, Cupissol D, Goldstein A: Thymosin modulation of suppressor function in mice and man. Ann NY Acad Sci 332:95-100, 1979

25. Hersh EM, Patt YZ, Murphy SG, Dicke K, Zander A, Adegbite M, Goldman R: Radiosensitive, thymic hormonesensitive peripheral blood suppressor cell activity in cancer patients. Cancer Res 40:3134-3140, 1980

26. Ahmed A, Wong DM, Thurman GB, Low TLK, Goldstein AL, Sharkis SJ, Goldschneider I: T-lymphocyte maturation: Cell surface markers and immune function induced by $\mathrm{T}$ lymphocyte cell-free products and thymosin polypeptides. Ann NY Acad Sci 332:81-94, 1979

27. Leevy CM, Popper H, Sherlock S: Diseases of the Liver and Biliary Tract: Standardization of Nomenclature, Diagnostic Criteria, and Diagnostic Methodology. DHEW Publication No. (NIH) 77-725. Washington, DC, Government Printing Office, 1977, pp 9-11

28. Scheinberg MA, Blacklow NR, Goldstein AL, Parrino TA, Rose FB, Cathcart ES: Influenza: Response of T-cell lymphopenia to thymosin. N Engl J Med 294:1208-1211, 1976

29. Hooper JA, McDaniel MC, Thurman GB, Cohen GH, Schulof RS, Goldstein AL: Purification and properties of bovine thymosin. Ann NY Acad Sci 249:125-144, 1975

30. Shou L, Schwartz SA, Good RA: Suppressor cell activity after concanavalin A treatment of lymphocytes from normal donors. J Exp Med 143:1100-1110, 1976

31. Mutchnick MG, Prieto JA, Schaffner JA, Weller FE: Thymosin modulation of regulatory $\mathrm{T}$ cell function. Clin Immunol Immunopathol 23:626 -633, 1982

32. Bresnihan B, Jasin HE: Suppressor function of peripheral blood mononuclear cells in normal individuals and in patients with systemic lupus erythematosus. J Clin Invest 59:106-116, 1977

33. Feighery C, Whelan CA, Weir DG, Greally JF: In vitro 
studies of suppressor cell function in human peripheral blood mononuclear cells. Clin Exp Immunol 32:459-465, 1978

34. Dwyer JM, Johnson C, Desaules M: Behavior of human immunoregulatory cells in culture. I. Variables requiring consideration for clinical studies. Clin Exp Immunol 38:499_ 513, 1979

35. Krawitt EL, Albertini RJ, Webb DD, Chastenay BF, Holdstock G, MacPherson BR: Immune regulation and HLA types in chronic hepatitis. Hepatology 1:300-306, 1981

36. Schwartz SA, Shou L, Good RA, Choi YS: Suppression of immunoglobulin synthesis and secretion by peripheral blood lymphocytes from normal donors. Proc Natl Acad Sci USA 74:2099-2103, 1977

37. Lydyard PM, Hayward AR: Induction of suppression through human $\mathrm{T}$ cell interactions. Clin Exp Immunol 39:496-502, 1979

38. Broder S, Waldman TA: The suppressor-cell network in cancer. N Engl J Med 299:1335-1341, 1978

39. Wolf RE, Goldstein AL, Ziff M: Suppression by thymosin of pokeweed mitogen-induced differentiation by human $B$ cells. Clin Immunol Immunopathol 11:303-306, 1978

40. Wolf RE: Thymosin-induced suppression of proliferative response of human lymphocytes to mitogens. J Clin Invest 63:677-683, 1979

41. Sakane T, Steinberg AD, Green I: Studies of immune functions of patients with systemic lupus erythematosus. I. dysfunction of suppressor T-cell activity related to impaired generation of, rather than response to, suppressor cells. Arthritis Rheum 21:657-664, 1978

42. Klassen LW, Krakawer RS, Steinberg AD: Selective loss of suppressor cell function in New Zealand mice induced by NTA. J Immunol 119:830-837, 1977
43. Elson CO, Graeff AS, James SP, Strober W. Covert suppressor T cells in Crohn's disease. Gastroenterology 80:15131521,1981

44. Kaplan J, Peterson WD: Detection of human T-lymphocyte antigens (HTLA antigens) in thymosin-inducible T-cell precursors. Clin Immunol Immunopathol 9:436-442, 1978

45. Scheinberg MA, Cathcart PS, Goldstein AL: Thymosininduced reduction of "null cells" in peripheral-blood lymphocytes of patients with systemic lupus erythematosus. Lancet 1:424-429, 1975

46. Horowitz SD, Goldstein AL: The in vitro induction of differentiation of putative human stem cells by thymosin and agents that affect cyclic AMP. Clin Immunol Immunopathol 9:408-418, 1978

47. Thomas HC, Freni M, Sanchez-Tapias J, De Villiers O, Jain S, Sherlock S: Peripheral blood lymphocyte populations in chronic liver disease. Clin Exp Immunol 26:222-227, 1976

48. Thurman GB, Marshall GD, Low TLK, Goldstein AL: Thymosin: Structural studies and immuno-regulatory role in host immunity. In Thymus, Thymic Hormones and T Lymphocytes. F Aiuti, H Wigzell (eds). New York, Academic Press, 1980, pp 1975-1985

49. Allison AC, Denman AM, Barnes RD: Cooperating and controlling functions of thymus-derived lymphocytes in relation to autoimmunity. Lancet 2:135-140, 1971

50. Parks DE, Weigle WO: Current perspectives in the cellular mechanisms of immunologic tolerance. Clin Exp Immunol 39:257-262, 1980

51. Miller KB, Schwartz RS: Familial abnormalities of suppressor cell function in systemic lupus erythematosus. N Engl J Med 301:803-809, 1979 